\title{
EDITORIAL
}

\section{Um Ano de Oportunidades}

A oportunidade de compor o corpo editorial da Revista de Medicina, assim como o arsenal de atividades desenvolvidas pelos graduandos da FMUSP, oferece contato único com diferentes áreas do saber que ultrapassam os conhecimentos apreendidos durante o curso regular. Destaca-se a imersão no meio da pesquisa e escrita científica que esse ano de editoração segue, há décadas, propiciando aos alunos que se aventuram em dedicar um período de sua formação à fomentar e manter ativas as publicações desta revista.

Os frutos do empenho de colegas de turmas anteriores constituem pilar primordial do crescimento do periódico que apresenta, atualmente, maiores números de alcance de leitores, de submissões e revisores de outras instituições. Não obstante do grande avanço conquistado pela Revista de Medicina através de seus colaboradores, o esforço para expandir novos volumes aumenta à medida que novas metas são elaboradas pelos editores, o que possibilita a dinamicidade da coordenação e constante aprimoramento dos alicerces do periódico.

Ressalta-se ainda a importância que a rede de apoio formada por antigos editores e revisores desempenha na elaboração das publicações; de tal modo, o trabalho dos novos editores é frequentemente complementado e auxiliado pelas experiências dos colegas, visando sempre as melhores soluções. Agraciados pelo contato constante com textos científicos exclusivos oriundos de diversas instituições conceituadas, os alunos do Corpo Editorial compreendem a necessidade de fomentar a pesquisa e produção de artigos no meio acadêmico.

É fato que, desde a inauguração deste periódico, a gestão é composta exclusivamente por alunos da graduação, e esse fato implica na importância de administrar desafios particulares apresentados ao longo do processo de produção das edições, que contemplam não somente, mas também, a constante aquisição de novos contatos profissionais de âmbitos diversos dispostos à cordialmente coletar ou elaborar o que há de mais recente e inovador em sua respectiva área. Essa conjuntura, essencialmente ausente aos graduandos não diretamente comprometidos à área de pesquisa, configura brecha ímpar no aprendizado pessoal e profissional dos envolvidos.

Dessa forma, destaca-se que uma das finalidades de todo procedimento relativo às novas edições tem como objetivo estimular, de maneira progressiva e natural, a busca de novos horizontes do conhecimento pelos leitores - vasta parcela também composta por alunos da graduação - e se tal propósito seguir seu cumprimento, com satisfação o compromisso da presente gestão dará continuidade em aprimorar e perpetuar a Revista de Medicina para as gerações futuras.

Ótima leitura a todos.

\author{
Paula Coelho Gyori \\ Luiz Gustavo de Oliveira Gonçalves \\ Acadêmicos de Medicina da FMUSP \\ Editores da Revista de Medicina - Gestão 2018
}

